\title{
Beyond the 6-week check-up: exploring the use of physical activity to improve depressive symptoms in women after perinatal loss
}

\author{
Jennifer Huberty \\ From Stillbirth Summit 2014 \\ Medina, MN, USA. 19-21 June 2014
}

The labor, birth, and postpartum periods of women who experience stillbirth are physically similar to women with live birth; however, the negative effects are significantly greater [1]. Women with stillbirth are at three times the risk of depressive symptoms when compared to women with live birth [2]. Depressive states may contribute to weight retention or gain, increased risk of chronic disease (i.e., heart disease), and poor quality of life, and can negatively impact the health of babies born subsequent to loss [3]. Unfortunately, inter-conception interventions to improve the mental and physical health of women after stillbirth are marginal. Treatment may include psychiatric medications and a referral to loss support groups $[1,4]$. However, these modalities do not consider the unique mental and physical health needs of bereaved mothers, nor do they take into consideration that a majority of women with stillbirth are pregnant or seeking pregnancy within the first year [6-8], and subsequently desire non-pharmacological interventions to cope with their symptoms.

Little is known about using physical activity as a nonpharmacological intervention to cope with stillbirth, despite its known efficacy in improving depressive symptoms in pregnant and postpartum women $[8,9]$. Women who are active during and after pregnancy have fewer depressive symptoms and report better mood as compared to inactive pregnant and post-partum women $[10,11]$. This may also be true for women with stillbirth. In a recent qualitative study [12] women with stillbirth who reported regular physical activity participation experienced mental, emotional, and physical benefits that helped them cope with their grief. Even those that

Correspondence: Jennifer.Huberty@asu.edu

Arizona State University, School of Nutrition \& Health Promotion, Phoenix, Arizona, USA 
barriers related to physical activity and encourage and guide women to use physical activity to cope with their grief, and (4) home-based interventions that incorporate yoga as a means to cope with depressive symptoms. More research is warranted.

Published: 15 April 2015

\section{References}

1. Hughes PM, Turton P, Evans CDH: Stillbirth as a risk factor for depression and anxiety in the subsequent pregnancy: a cohort study. BMJ 1999, 14:1721-1724.

2. Hogue CJR, Parker CB, Willinger $M$, Hogue CJR et al.: Paediatric and Perinatal Epidemiology 2015, 29(2):131-143.

3. Lacasse JR, Cacciatore J: Prescribing of psychiatric medication to bereaved parents following perinatal/neonatal death: an observational study. Death Studies 2014, 0:1-8.

4. Côté-Arsenault D, Marshall R: One foot in-one foot out: weathering the storm of pregnancy after perinatal loss. Research in Nursing \& Health 2000, 23:473-485.

5. Gaudet C: Pregnancy after perinatal loss: association of grief, anxiety and attachment. Journal of Reproductive and Infant Psychology 2010, 28:240-251.

6. DeBackere KJ, Hill PD, Kavanaugh KL: The parental experience of pregnancy after perinatal loss. JOGNN 2008, 37:525-537.

7. Babyak M, Blumenthal J, Herman S, Khatri P, Doraiswamy M, Moore K, Edward CW, Baldewicz T, Krishnan K: Exercise treatment for major depression: maintenance of therapeutic benefit at 10 months. Psychosomatic Medicine 2000, 62:633-638.

8. Herring MP, Puetz TW, O'Connor PJ, Dishman RK: Effect of exercise training on depressive symptoms among patients with a chronic illness: a systematic review and meta-analysis of randomized controlled trials. Arch Intern Med 2012, 72:101-111.

9. Teychenne M, York R: Physical activity, sedentary behavior, and postnatal depressive symptoms: a review. Am J Prev Med 2013, 45:217-227.

10. Evenson KR: Towards an understanding of change in physical activity from pregnancy through postpartum. Psych Sport Exerc 2011, 12:36-45.

11. Huberty JL, Coleman J, Rolfsmeyer K, Wu S: A qualitative study exploring women's beliefs about physical activity after stillbirth. BMC Pregnancy \& Childbirth 2014, 14:1471-2393.

12. Huberty JL, Leifeman J, Gold KJ, Rowedder L, Cacciatore J, Bonds D: Physical activity and depressive symptoms after stillbirth: informing interventions. BMC Pregnancy and Childbirth 2014, 14:391, doi:10.1186/ s12884-014-0391-1.

\section{doi:10.1186/1471-2393-15-S1-A18}

Cite this article as: Huberty: Beyond the 6-week check-up: exploring the use of physical activity to improve depressive symptoms in women after perinatal loss. BMC Pregnancy and Childbirth 2015 15(Suppl 1):A18.

\section{Submit your next manuscript to BioMed Central and take full advantage of:}

- Convenient online submission

- Thorough peer review

- No space constraints or color figure charges

- Immediate publication on acceptance

- Inclusion in PubMed, CAS, Scopus and Google Scholar

- Research which is freely available for redistribution

Submit your manuscript at www.biomedcentral.com/submit
C) Biomed Central 